\title{
Studies on the effect of exogenous application of salicylic acid on post-harvest quality and shelf life of tomato fruit Cv. Abhinav
}

\author{
Chavan R.F. and *Sakhale B.K. \\ Department of Chemical Technology, Dr. Babasaheb Ambedkar Marathwada University, Aurangabad- \\ 431004, M.S., India
}

\begin{abstract}
Article history:
April 2020

2020

Keywords:

Tomato,

Salicylic acid,

Shelf life,

Post-harvest,

Texture,

Lycopene
\end{abstract}

Received: 24 March 2020

Received in revised form: 9

Accepted: 14 April 2020

Available Online: 2 May

\section{DOI:}

https://doi.org/10.26656/fr.2017.4(5).131

\begin{abstract}
An investigative research experiment was undertaken to study the effect of exogenous application of salicylic acid on tomato fruit of Cv. Abhinav during its storage period at $24^{\circ} \mathrm{C}$. The fresh tomato fruits (Lycopersicon esculentum Mill.) of $\mathrm{Cv}$. Abhinav were harvested at the proper stage of physiological maturity. The fruits were washed thoroughly with clean water followed by fungicidal treatment of $500 \mathrm{ppm}$ benomyl before salicylic acid treatment. Thereafter, the fungicide treated tomato fruits were subdivided into four different lots and then immersed in salicylic acid (SA) solutions at 50, 100, 150 and 200 ppm concentrations for 30 mins respectively and kept for storage studies along with control fruits. During the storage period, the observations were recorded at frequent intervals for various physico-chemical parameters in which tomatoes treated at 200ppm salicylic acid concentration found significant with respect to the lower physiological loss in weight (10.3\%), a gradual increase in TSS and colour (h) from 1.4 to $3.3^{\circ}$ Brix and -3.63 to 2.59 respectively. Moreover, the considerable decrease was observed in titrable acidity from 1.34 to $0.14 \%$, Ascorbic Acid (SA) content from 73.14 to $22.10 \mathrm{mg} / 100 \mathrm{~g}$ and texture in terms of firmness decreased from 354 to $96 \mathrm{gf}$. The total phenolic content of $200 \mathrm{ppm}$ salicylic acid treated tomatoes showed a gradual decrease from 3.79 to $3.14 \mathrm{mg}$ $\mathrm{GAE} / \mathrm{g}$ and lycopene content increased slowly from 7.01 to $12.31 \mathrm{mg} / 100 \mathrm{~g}$ therefore, found significant as compared to rest of the treatments and control fruits.
\end{abstract}

\section{Introduction}

Tomato is a major contributor of carotenoids (especially lycopene), phenolics, vitamin $\mathrm{C}$ and small amounts of vitamin $\mathrm{E}$ in daily diets (Khachik et al., 2002). The two main carotenoids in tomato fruits are lycopene which imparts the red colour to the tomato and carotene which accounts for approximately $7 \%$ of tomato carotenoid content. Tomato fruits are also rich in phenolic compounds, which are considered as potentially health-promoting substances due to their anti-oxidative, anti-cancer, anti-diabetic and cardiovascular protective effects. Tomatoes contain quercetin, naringenin, rutin and chlorogenic acid as the main phenolic compounds, which along with ascorbic acid is determinant of the hydrophilic antioxidant activity. Due to carotenoids, lycopene and $\beta$-carotene, tomatoes have high nutritional value (Rao et al., 2000).

Ethylene plays a key role in the ripening of climacteric fruits such as tomato by triggering several ripening related physiological changes and its ripening is highly dependent on ethylene action (Lelievre et al., 1997). But the production of excess ethylene leads to over-ripening and facilitates microbial growth thereby reducing the shelf life. Therefore, control over ethylene action is required. Global estimates of losses for fruits and vegetables after harvest ranges as high as 30 to 40 $\%$, with much of these losses occurring in regions of tropical fruit production. The rapid ripening of fruit after harvest limits storability and is a concern during transportation and marketing. Therefore, delaying the ripening, one approach involves inhibition of ethylene action. Ethylene synthesis and action in fruits can be affected by low temperature storage, controlled or modified atmosphere and application of ethylene antagonists such as salicylic acid (Fung et al., 2004).

Many compounds have shown the ability to block the ethylene binding site, causing either the suppression or the inhibition of ethylene effects (Sisler and Serek, 1997). However, none of these compounds is commercially acceptable due to toxicity and 
manufacturing concerns (Fan et al., 1999) but salicylic acid unlike other compounds has no proven potential toxicity so far and therefore may be undertaken for its application on different fruits in order to make it more commercially viable and reliable ethylene antagonist compound.

Thus, salicylic acid (SA), a plant hormone plays an important role in the induction of plant defense against a variety of biotic and abiotic stresses through morphological, physiological and biochemical mechanisms. The function of exogenous salicylic acid at non-toxic concentrations has been exposed for delaying the ripening and softening of banana (Srivastava and Dwivedi, 2000) and it has also been used for different crops to prolong their shelf life. Many physiological, biochemical and structural changes occur during fruit repining which induces starch degradation or other polysaccharides to produce sugars. Therefore, the aim of this study was to utilize the metabolic roles of salicylic acid to delay the ripening of tomato to extend the shelf life and hence the present investigation was undertaken to provide a better understanding of the role of SA in the control of tomato fruit specifically of cv. Abhinav variety ripening and its effect on various physicochemical parameters during storage.

\section{Materials and methods}

The present study was carried out in the Food Technology Laboratory, Department of Chemical Technology, Dr Babasaheb Ambedkar Marathwada University, Aurangabad.

\subsection{Materials}

Tomato fruit harvested at breaker stage of maturity of Cv. Abhinav. The good quality analytical grade chemicals including benomyl fungicide, BHT, hexanal, ethanol, Folin-Ciocalteu reagent, methanol and acetone were obtained from the reputed manufacturers. Salicylic acid powder procured from Himedia Laboratory Chemicals Limited. The sophisticated analytical instruments available in the Food technology laboratories were effectively and efficiently used in the present research work. The instruments like Cool Chamber (Nanolab India), Minolta Colorimeter (Model-CR-10, Konica, Japan), Handheld Digital Refractometer (PAL-3, Atago, Japan), Analytical Weighing Balance, etc. were used for carrying out analytical processes.

\subsection{Selection of tomato fruits}

The fresh tomato fruits (Lycopersicon esculentum Mill.) of Cv. Abhinav were harvested at breaker stage from well-managed commercial farms of village
Devgaon Rangari from Aurangabad district of Maharashtra, India. The fruits were washed thoroughly with clean water and then prepared for the treatments.

\subsection{Treatment of salicylic acid}

Tomatoes harvested at breaker stage of maturity were selected, washed and graded on the basis of their specific gravity and given the benomyl fungicidal application of $500 \mathrm{ppm}$ for 20 mins followed by salicylic acid treatment at various concentrations as per Table 1 viz. 50, 100, 150 and $200 \mathrm{ppm}$ by immersing in salicylic acid solutions for 30 mins respectively and stored along with absolute control sample at $24^{\circ} \mathrm{C}$.

Table 1. Treatment details of salicylic acid concentration, storage period and storage

\begin{tabular}{|c|c|}
\hline Treatment & Treatment details \\
\hline $\mathrm{T}_{0}$ & $\begin{array}{l}\text { Control Fruit (Tomato) }+24{ }^{\circ} \mathrm{C} \text { Storage } \\
\text { temperature }\end{array}$ \\
\hline $\mathrm{T}_{1}$ & $\begin{array}{l}\text { Salicylic acid - 50ppm }+24{ }^{\circ} \mathrm{C} \text { Storage } \\
\text { temperature }\end{array}$ \\
\hline $\mathrm{T}_{2}$ & $\begin{array}{l}\text { Salicylic acid - } 100 \mathrm{ppm}+24{ }^{\circ} \mathrm{C} \text { Storage } \\
\text { temperature }\end{array}$ \\
\hline $\mathrm{T}_{3}$ & $\begin{array}{l}\text { Salicylic acid - } 150 \mathrm{ppm}+24{ }^{\circ} \mathrm{C} \text { Storage } \\
\text { temperature }\end{array}$ \\
\hline $\mathrm{T}_{4}$ & $\begin{array}{l}\text { Salicylic acid - 200ppm }+24{ }^{\circ} \mathrm{C} \text { Storage } \\
\text { temperature }\end{array}$ \\
\hline
\end{tabular}

2.4 Physicochemical analysis of tomato fruits

Various physicochemical analyses of the control and treated fruits were carried out in order to determine the effect of treatments of salicylic acid on quality and shelf life extension of tomato fruit. The observations were recorded at frequent intervals of 4 days during the storage period for various parameters.

\subsubsection{Percent physiological loss in weight of fruit}

Physiological loss in weight of tomato fruit was calculated by using analytical weighing balance to determine the degree of maturity during the storage of salicylic acid treated and control fruit samples by the method suggested by Nunes (2008).

\subsubsection{Surface colour}

Color value $\mathrm{L}$, $\mathrm{a}$ and $\mathrm{b}$ was determined using a colorimeter (Konica Minolta CR-10) with a standard CIE illuminant and by calculating the hue angle by using formula given by Bai et al. (2004).

$$
\text { Hue angle }(\mathrm{h})=\operatorname{Tan}^{-1} .(\mathrm{B} / \mathrm{A})
$$

\subsubsection{Fruit firmness}

The textural characteristic of tomatoes in terms of firmness was determined by using a texture analyzer (TMS-Pro, FTC, USA). The fruit was placed below probe and the $5 \mathrm{~mm}$ diameter probe with $1 \mathrm{~mm} / \mathrm{s}$ test 
speed and $0.5 \mathrm{~N}$ trigger force was inserted into the surface of fruits at $10 \mathrm{~mm}$ distance. The maximum force generated during probe's travel was measured in gram force (gf) and the results in terms of firmness were expressed in gram force (gf) as described by Xie et al. (2009).

\subsubsection{Total soluble solids}

The total soluble solid ( ${ }^{\circ}$ Brix) in the fruits was recorded by Atago digital Pocket Refractometer PAL-3 (AOAC, 2016). For precision and accuracy of the values, the prism of refractometer was washed with distilled water and wiped dry before every reading.

\subsubsection{Titrable acidity}

Total titrable acidity of salicylic acid treated tomato fruits was determined by titrating the extracted juice against $0.1 \mathrm{~N} \quad \mathrm{NaOH}$ (sodium hydroxide) using phenolphthalein as an indicator and expressed as oxalic acid content in percentage as suggested by Ranganna (2002).

\subsubsection{Ascorbic acid content}

The ascorbic acid content of tomatoes was estimated by using 2, 6 dichlorophenol indophenols dye titration method (Ranganna, 2002; AOAC, 2016) and expressed as $\mathrm{mg} 100 \mathrm{~g}^{-1}$.

\subsubsection{Total phenolic content}

The total phenolic contents of the tomatoes extracted by methanol determined by reading absorbance on UVVIS Spectrophotometer (LABINDIA-3000+plus, India) at $765 \mathrm{~nm}$ using Folin-Ciocalteu reagent as with slight modification in the analytical method given by Singleton (1974). The results were expressed as gallic acid as a standard in $\mathrm{mg}$ gallic acid equivalents per gram (mg $\mathrm{GAE} / \mathrm{g}$ ) of tomato fruits.

\subsubsection{Lycopene content}

The lycopene content of the tomato fruits during storage period was estimated as per the method specified by Fish et al. (2002) and modified by Ranveer et al.
(2013). Extraction was carried out by using solvents such as BHT, acetone and ethanol with the help deionized water and thus allowing the mixture for phase separation followed by dilution of the uppermost solvent layer with the addition of hexanal in 1:10 proportion. Later on, the absorbance of the same was measured at $503 \mathrm{~nm}$ by using UV-Vis Spectrophotometer (Model Make, 3000+ LabIndia)

$$
\text { Lycopene }(\mu \mathrm{g} / \mathrm{g})=\frac{\text { Absorbance } \times 31.2 \times \text { Dilution }}{\text { gram of sample }}
$$

\section{Results and discussion}

3.1 Effect of salicylic acid on physiological loss (\%) in weight (PLW) of tomato fruit

The percentage of physiological loss in weight PLW (\%) and colour of tomatoes are important physical quality parameters determining wholesomeness and shelf life of any fruits. The phase transformation from maturity to senescence which results in spoilage of fruit is identified by these quality parameters. Results in Table 2 showed that PLW of control sample increased from 2.9 to $12.3 \%$ within 12 days of storage. The tomatoes which were treated at $200 \mathrm{ppm}$ salicylic acid concentration showed a very gradual increase in PLW from 2.8 to $10.3 \%$ on 32 days of their shelf life with better retention of quality parameters than any other treatments. The increases in the percentage of PLW of tomato might be due to the transpiration of tomato in the $24^{0} \mathrm{C}$ storage condition and results were found in close proximity with Park et al. (2016).

\subsection{Effect of salicylic acid treatment on surface colour of tomato fruits}

As shown in Table 3, the decrease in L values in the last days of storage lead changes in hue angle. Control samples showed rapid increase the lightness value from 3.28 to 4.97 within 12 days of storage period whereas $\mathrm{T}_{4}$ samples which were treated with 200 ppm salicylic acid showed slow changes in color values up to their maximum shelf life of 32 days. The surface color of tomatoes in $\mathrm{T}_{4}$ treatment observed turning red from faint yellow color in gradual manner as shown in Figure 1

Table 2. Effect of salicylic acid on physiological loss in weight (PLW) of tomato fruits (\%)

\begin{tabular}{|c|c|c|c|c|c|c|c|c|c|}
\hline \multirow{2}{*}{ Treatments } & \multicolumn{9}{|c|}{ Storage Period (Days) } \\
\hline & 0 & 4 & 8 & 12 & 16 & 20 & 24 & 28 & 32 \\
\hline $\mathrm{T}_{0}$ & 0 & 4.9 & 8.7 & 12.9 & $*$ & $*$ & $*$ & $*$ & $*$ \\
\hline $\mathrm{T}_{1}$ & 0 & 2.7 & 4.3 & 8.5 & 11.8 & $*$ & $*$ & $*$ & $*$ \\
\hline $\mathrm{T}_{2}$ & 0 & 3.1 & 4.9 & 6.7 & 8.9 & 11.7 & $*$ & $*$ & $*$ \\
\hline $\mathrm{T}_{3}$ & 0 & 3 & 4.7 & 6.3 & 8.4 & 9.5 & 10.8 & $*$ & $*$ \\
\hline $\mathrm{T}_{4}$ & 0 & 2.8 & 3.5 & 5.3 & 7.2 & 8.8 & 9.1 & 9.8 & 10.3 \\
\hline Mean \pm SD & $0 \pm 0$ & $3.3 \pm 0.8$ & $5.2 \pm 1.8$ & $7.9 \pm 2.7$ & $7.2 \pm 3.9$ & $6.0 \pm 5.0$ & $4.0 \pm 4.9$ & $2.0 \pm 3.9$ & $2.1 \pm 4.1$ \\
\hline
\end{tabular}

$\mathrm{T}_{0}$ : Control, $\mathrm{T}_{1}: 50 \mathrm{ppm}, \mathrm{T}_{2}: 100 \mathrm{ppm}, \mathrm{T}_{3}: 150 \mathrm{ppm}, \mathrm{T}_{4}: 200 \mathrm{ppm}$. ${ }^{*}$ Discarded due to spoilage 


\section{Control fruits}

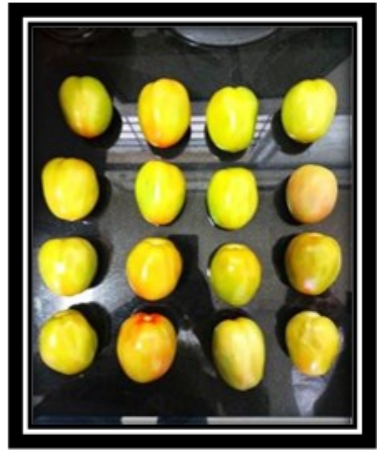

Day-0

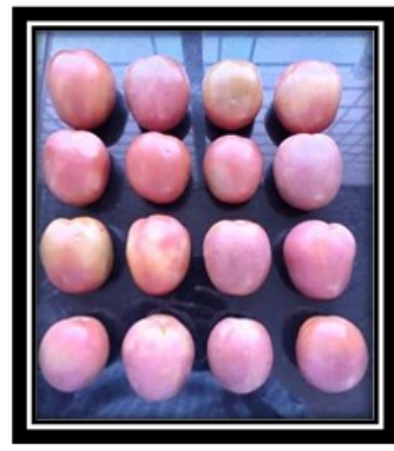

Day-4

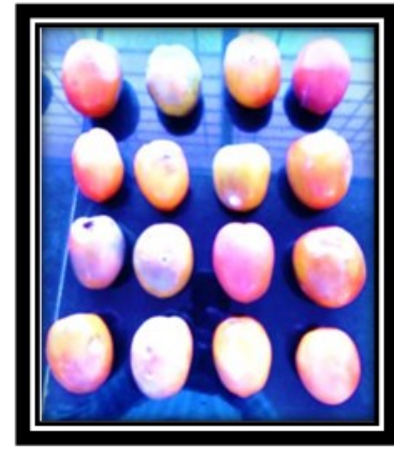

Day-12

2. Effect of salicylic acid on tomato fruits at $200 \mathrm{ppm}$ concentration

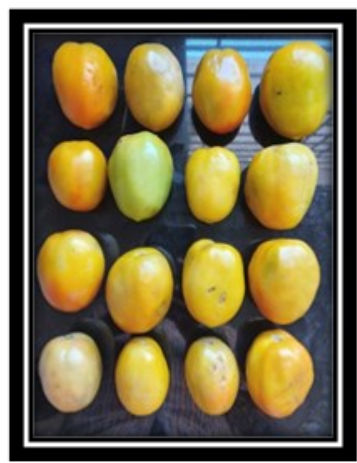

Day-0

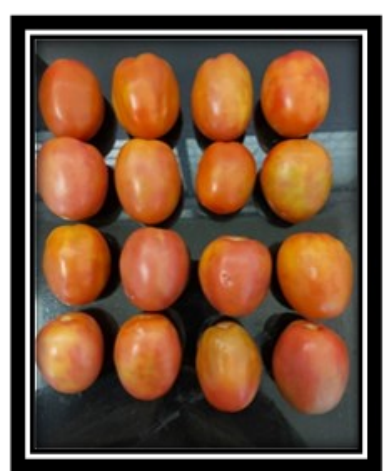

Day-16

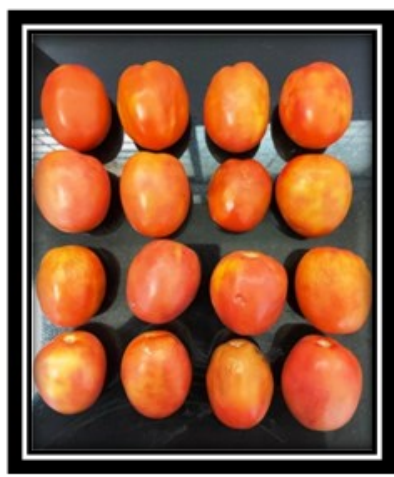

Day-32

Figure 1. Effect of salicylic acid on tomato fruits cv. Abhinav during storage

appeared quite significant and acceptable as compared with other treatments. Asghari and Aghdam (2010).

\subsection{Effect of salicylic acid treatments on firmness of tomato fruits}

Texture or firmness of tomato fruits expressed in gram force gives an idea about the overall quality of the fruits during storage. Higher values indicate the firm or hard texture of tomatoes which is a good indicator of the maturity stage of a particular fruit and hence useful in determining quality at a particular storage period. Significant retention of firmness was observed in tomatoes treated with salicylic acid as compared with untreated control fruits. As shown in Figure 2, the most significant results were shown by fruits treated with 200 ppm salicylic acid in which, at the end of the 32 days storage life the firmness was 96 gf which was far better than the control fruits which lasted only for 12 days with 69 gf firmness due to loss of rigidity of tissues during ripening (Bhowmik and Pan, 1992).

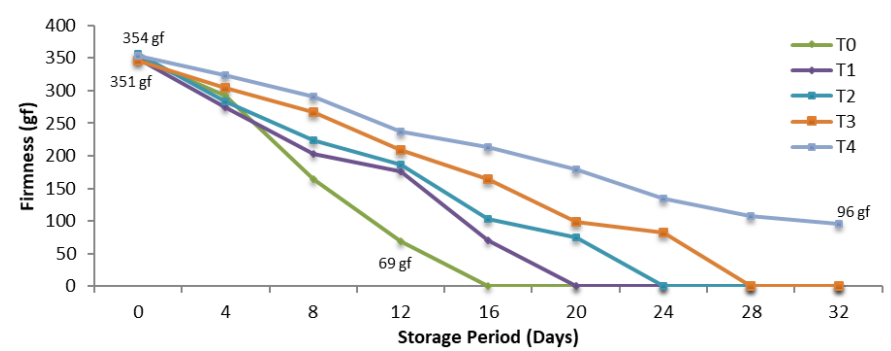

Figure 2. Effect of salicylic acid on firmness (gf) of tomato fruits
3.4 Effect of salicylic acid treatment on TSS of tomato fruits

Total soluble solids content (TSS) is one of the most important quality parameters of the fruits and indicates the degree of ripening. The effect of salicylic acid concentrations, exposure time and storage temperatures on the TSS content of fruits were studied and the results obtained are presented in Table 4.

All the fruits which were given salicylic acid treatment shown a very gradual change in TSS except the control fruits which showed rapid change in TSS from 1.3 to $2.7^{\circ}$ Brix within very less shelf life of only 12 days as compared with salicylic acid treated fruits at 200 ppm which was having shelf life of 32 days. The TSS of tomatoes having given the $\mathrm{T}_{4}$ treatment was $3.3^{\circ} \mathrm{Brix}$ even on the $32^{\text {nd }}$ day of its storage period which was superior to any other treatments which found similar with the investigations reported by Gharezi et al. (2012).

\subsection{Effect of salicylic acid treatment on titrable acidity (\%) of tomato fruits}

Titrable acidity is one among the two major parameters which determine the wholesomeness of any fruits other being TSS as far as the keeping quality fruits is concerned. Table 5 shows the effect of salicylic acid treatment on the percent titrable acidity of the tomatoes. The tomatoes treated with salicylic acid at $200 \mathrm{ppm}$ and stored at $24^{\circ} \mathrm{C}$ temperature recorded highest shelf life of 
Table 3. Effect of salicylic acid on surface color (hue angle) of tomato fruits

\begin{tabular}{|c|c|c|c|c|c|c|c|c|c|}
\hline \multirow{2}{*}{ Treatments } & \multicolumn{9}{|c|}{ Storage Period (Days) } \\
\hline & 0 & 4 & 8 & 12 & 16 & 20 & 24 & 28 & 32 \\
\hline $\mathrm{T}_{0}$ & -3.28 & 1.74 & 2.46 & 4.97 & * & $*$ & * & $*$ & * \\
\hline $\mathrm{T}_{1}$ & -3.32 & 1.34 & 1.69 & 2.16 & 4.68 & $*$ & $*$ & $*$ & $*$ \\
\hline $\mathrm{T}_{2}$ & -3.21 & 1.49 & 2.07 & 2.93 & 3.87 & 4.42 & $*$ & $*$ & $*$ \\
\hline $\mathrm{T}_{3}$ & -3.28 & 2.53 & 2.73 & 3.09 & 3.44 & 3.47 & 4.11 & $*$ & $*$ \\
\hline $\mathrm{T}_{4}$ & -3.19 & 1.23 & 1.53 & 1.85 & 2.39 & 2.97 & 3.26 & 3.48 & 4.01 \\
\hline Mean \pm SD & $3.3 \pm 0.0$ & $1.7 \pm 0.5$ & $2.1 \pm 0.5$ & $3.0 \pm 1.1$ & $2.9 \pm 1.6$ & $2.2 \pm 1.8$ & $1.5 \pm 1.8$ & $0.7 \pm 1.4$ & $0.8 \pm 1.6$ \\
\hline
\end{tabular}

$\mathrm{T}_{0}$ : Control, $\mathrm{T}_{1}: 50 \mathrm{ppm}, \mathrm{T}_{2}: 100 \mathrm{ppm}, \mathrm{T}_{3}: 150 \mathrm{ppm}, \mathrm{T}_{4}: 200 \mathrm{ppm}$. ${ }^{*}$ Discarded due to spoilage

Table 4. Effect of salicylic acid treatment on TSS ( $\left.{ }^{\circ} \mathrm{Brix}\right)$ of tomato fruits

\begin{tabular}{|c|c|c|c|c|c|c|c|c|c|}
\hline \multirow{2}{*}{ Treatments - } & \multicolumn{9}{|c|}{ Storage Period (Days) } \\
\hline & 0 & 4 & 8 & 12 & 16 & 20 & 24 & 28 & 32 \\
\hline $\mathrm{T}_{0}$ & 1.3 & 1.5 & 1.9 & 2.7 & $*$ & * & * & $*$ & * \\
\hline $\mathrm{T}_{1}$ & 1.5 & 1.8 & 2.1 & 2.3 & 2.6 & $*$ & $*$ & $*$ & $*$ \\
\hline $\mathrm{T}_{2}$ & 1.4 & 1.7 & 1.9 & 2.1 & 2.7 & 2.9 & $*$ & $*$ & * \\
\hline $\mathrm{T}_{3}$ & 1.2 & 1.4 & 1.4 & 1.5 & 1.9 & 2.3 & 3.1 & $*$ & $*$ \\
\hline $\mathrm{T}_{4}$ & 1.4 & 1.5 & 1.9 & 2.1 & 2.3 & 2.7 & 2.9 & 3.1 & 3.3 \\
\hline Mean \pm SD & $1.4 \pm 0.1$ & $1.6 \pm 0.1$ & $1.8 \pm 0.2$ & $2.1 \pm 0.4$ & $1.9 \pm 1.0$ & $1.6 \pm 1.3$ & $1.2 \pm 1.5$ & $0.6 \pm 1.2$ & $0.7 \pm 1.3$ \\
\hline
\end{tabular}

$\mathrm{T}_{0}$ : Control, $\mathrm{T}_{1}: 50 \mathrm{ppm}, \mathrm{T}_{2}: 100 \mathrm{ppm}, \mathrm{T}_{3}: 150 \mathrm{ppm}, \mathrm{T}_{4}: 200 \mathrm{ppm}$. ${ }^{*}$ Discarded due to spoilage

Table 5. Effect of salicylic acid treatment on titrable acidity (\%) of tomato fruits

\begin{tabular}{|c|c|c|c|c|c|c|c|c|c|}
\hline \multirow{2}{*}{ Treatments - } & \multicolumn{9}{|c|}{ Storage Period (Days) } \\
\hline & 0 & 4 & 8 & 12 & 16 & 20 & 24 & 28 & 32 \\
\hline $\mathrm{T}_{0}$ & 0.39 & 0.31 & 0.23 & 0.11 & $*$ & * & $*$ & $*$ & * \\
\hline $\mathrm{T}_{1}$ & 0.37 & 0.30 & 0.26 & 0.18 & 0.13 & $*$ & $*$ & $*$ & $*$ \\
\hline $\mathrm{T}_{2}$ & 0.35 & 0.30 & 0.27 & 0.21 & 0.19 & 0.13 & $*$ & $*$ & $*$ \\
\hline $\mathrm{T}_{3}$ & 0.41 & 0.38 & 0.33 & 0.29 & 0.24 & 0.17 & 0.11 & $*$ & $*$ \\
\hline $\mathrm{T}_{4}$ & 0.38 & 0.35 & 0.32 & 0.29 & 0.27 & 0.23 & 0.19 & 0.15 & 0.11 \\
\hline Mean \pm SD & $0.4 \pm 0.0$ & $0.3 \pm 0.0$ & $0.3 \pm 0.0$ & $0.2 \pm 0.1$ & $0.2 \pm 0.1$ & $0.1 \pm 0.1$ & $0.1 \pm 0.1$ & $0.0 \pm 0.1$ & $0.0 \pm 0.0$ \\
\hline
\end{tabular}

$\mathrm{T}_{0}$ : Control, $\mathrm{T}_{1}: 50 \mathrm{ppm}, \mathrm{T}_{2}: 100 \mathrm{ppm}, \mathrm{T}_{3}: 150 \mathrm{ppm}, \mathrm{T}_{4}: 200 \mathrm{ppm}$. ${ }^{*}$ Discarded due to spoilage

Table 6. Effect of salicylic acid treatment on ascorbic acid content (mg/100 g) of tomato fruits

\begin{tabular}{|c|c|c|c|c|c|c|c|c|c|}
\hline \multirow{2}{*}{ Treatments } & \multicolumn{9}{|c|}{ Storage Period (Days) } \\
\hline & 0 & 4 & 8 & 12 & 16 & 20 & 24 & 28 & 32 \\
\hline $\mathrm{T}_{0}$ & 73.51 & 61.97 & 41.23 & 23.47 & $*$ & $*$ & $*$ & $*$ & $*$ \\
\hline $\mathrm{T}_{1}$ & 72.32 & 64.51 & 48.59 & 41.81 & 23.20 & $*$ & $*$ & $*$ & $*$ \\
\hline $\mathrm{T}_{2}$ & 74.58 & 68.93 & 51.98 & 45.2 & 37.29 & 23.2 & * & $*$ & $*$ \\
\hline $\mathrm{T}_{3}$ & 72.19 & 68.93 & 55.37 & 47.46 & 42.94 & 36.16 & 22.90 & $*$ & $*$ \\
\hline $\mathrm{T}_{4}$ & 73.14 & 66.67 & 49.72 & 44.07 & 40.68 & 37.29 & 35.03 & 31.64 & 22.10 \\
\hline $\operatorname{Mean} \pm \mathrm{SD}$ & $73.1 \pm 0.9$ & $66.2 \pm 2.7$ & $49.4 \pm 4.7$ & $40.4 \pm 8.7$ & $28.8 \pm 16$ & $19.3 \pm 16.5$ & $11.6 \pm 14.7$ & $6.3 \pm 12.7$ & $4.4 \pm 8.8$ \\
\hline
\end{tabular}

$\mathrm{T}_{0}$ : Control, $\mathrm{T}_{1}: 50 \mathrm{ppm}, \mathrm{T}_{2}: 100 \mathrm{ppm}, \mathrm{T}_{3}: 150 \mathrm{ppm}, \mathrm{T}_{4}: 200 \mathrm{ppm}$. ${ }^{*}$ Discarded due to spoilage

Table 7. Effect of salicylic acid treatment on total phenolic content (mg GAE/g) of tomato fruits

\begin{tabular}{|c|c|c|c|c|c|c|c|c|c|}
\hline \multirow{2}{*}{ Treatments } & \multicolumn{9}{|c|}{ Storage Period (Days) } \\
\hline & 0 & 4 & 8 & 12 & 16 & 20 & 24 & 28 & 32 \\
\hline $\mathrm{T}_{0}$ & 3.73 & 3.39 & 3.01 & 2.87 & $*$ & $*$ & $*$ & $*$ & $*$ \\
\hline $\mathrm{T}_{1}$ & 3.68 & 3.63 & 3.42 & 3.21 & 2.91 & $*$ & $*$ & $*$ & $*$ \\
\hline $\mathrm{T}_{2}$ & 3.85 & 3.78 & 3.67 & 3.53 & 3.29 & 3.11 & * & $*$ & $*$ \\
\hline $\mathrm{T}_{3}$ & 3.97 & 3.74 & 3.63 & 3.56 & 3.38 & 3.27 & 3.18 & $*$ & $*$ \\
\hline $\mathrm{T}_{4}$ & 3.79 & 3.73 & 3.66 & 3.59 & 3.51 & 3.43 & 3.34 & 3.22 & 3.14 \\
\hline Mean \pm SD & $3.8 \pm 0.1$ & $3.7 \pm 0.1$ & $3.5 \pm 0.3$ & $3.4 \pm 0.3$ & $2.6 \pm 1.3$ & $2.0 \pm 1.6$ & $1.3 \pm 1.6$ & $0.6 \pm 1.3$ & $0.6 \pm 1.3$ \\
\hline
\end{tabular}

$\mathrm{T}_{0}$ : Control, $\mathrm{T}_{1}: 50 \mathrm{ppm}, \mathrm{T}_{2}: 100 \mathrm{ppm}, \mathrm{T}_{3}: 150 \mathrm{ppm}, \mathrm{T}_{4}: 200 \mathrm{ppm}$.*Discarded due to spoilage 
Table 8. Effect of salicylic acid treatment on lycopene content $(\mathrm{mg} / 100 \mathrm{~g})$ of tomato fruits

\begin{tabular}{ccccccccccc}
\hline \multirow{2}{*}{ Treatments } & \multicolumn{1}{c}{ Storage Period (Days) } \\
\cline { 2 - 10 }$y$ & 0 & 4 & 8 & 12 & 16 & 20 & 24 & 28 & 32 \\
\hline $\mathrm{T}_{0}$ & 6.98 & 8.25 & 10.63 & 12.19 & $*$ & $*$ & $*$ & $*$ & $*$ \\
$\mathrm{~T}_{1}$ & 7.02 & 8.01 & 9.89 & 11.63 & 12.22 & $*$ & $*$ & $*$ & $*$ \\
$\mathrm{~T}_{2}$ & 6.89 & 7.87 & 9.13 & 10.69 & 11.13 & 12.20 & $*$ & $*$ & $*$ \\
$\mathrm{~T}_{3}$ & 6.94 & 7.73 & 8.97 & 9.98 & 10.87 & 11.46 & 12.23 & $*$ & $*$ \\
$\mathrm{~T}_{4}$ & 7.01 & 7.59 & 8.48 & 9.73 & 10.59 & 11.31 & 11.97 & 12.08 & 12.31 \\
Mean \pm SD & $7.0 \pm 0.0$ & $7.9 \pm 0.2$ & $9.4 \pm 0.8$ & $10.8 \pm 0.9$ & $6.5 \pm 5.3$ & $7.0 \pm 5.7$ & $4.8 \pm 5.9$ & $2.4 \pm 4.8$ & $2.5 \pm 4.9$ \\
\hline
\end{tabular}

$\mathrm{T}_{0}$ : Control, $\mathrm{T}_{1}: 50 \mathrm{ppm}, \mathrm{T}_{2}: 100 \mathrm{ppm}, \mathrm{T}_{3}: 150 \mathrm{ppm}, \mathrm{T}_{4}: 200 \mathrm{ppm}$.*Discarded due to spoilage

32 days with a significant decrease in the titrable acidity from 0.38 to 0.11 . This change in the percent titrable acidity was gradual and acceptable as compared to other treatments. In control fruits which kept good only for 12 days, the acidity changed drastically from 0.39 to $0.11 \%$. Similar findings were reported by Mandal et al. (2016).

3.6 Effect of salicylic acid treatment on ascorbic acid content $(\mathrm{mg} / 100 \mathrm{~g})$ of tomato fruits

Generally ascorbic acid content of any fruits decreases during the length of its storage period, therefore the estimation of its content at regular time intervals during storage indicates keeping quality characteristics of the stored fruits at a particular time period. Table 6 shows the ascorbic content of all the treatments during storage study of the fruits.

There was a significant difference in ascorbic acid content among salicylic acid treated and untreated fruits. Ascorbic acid content in fruits treated with highest salicylic acid concentration was found to be reduced gradually from 73.14 to $22.10 \mathrm{mg} / 100 \mathrm{~g}$ up to the $32^{\text {nd }}$ day of its storage life. However ascorbic content in untreated control fruits reduced drastically from 73.51 to $23.47 \mathrm{mg} / 100 \mathrm{~g}$ within only 12 days of their shelf life. This is attributed to long term storage reduces ascorbic acid content reported by Dokhanieh et al. (2016).

\subsection{Effect of salicylic acid treatment on total phenolic content of tomato fruits}

During storage of the salicylic acid treated tomato fruits, the total phenolic contents of the fruits didn't show any drastic change. However, the decrease in total phenolic content of the untreated fruits was slightly rapid as compared with treated fruits as shown in Table 7. Moreover, the fruit treated with $200 \mathrm{ppm}$ salicylic acid concentration had shown significant retention of total phenolic content and decrease in the total phenolic was very gradual i.e. from 3.79 to $3.14 \mathrm{mg} \mathrm{GAE} / \mathrm{g}$ at the end of its shelf life of 32 days which found closely related with the research findings published by Mandal et al. (2016).
3.8 Effect of salicylic acid treatment on lycopene content of tomato fruits

From the lycopene values mentioned in Table 8 , it clearly depicts that the untreated tomato fruits showed a sudden increase in lycopene content due to rapid ripening. Whereas the fruits treated with salicylic acid showed a gradual increase in lycopene content specifically in case of $200 \mathrm{ppm}$ treated fruits the lycopene content was increased gradually from 7.01 to $12.31 \mathrm{mg} / 100 \mathrm{~g}$ which shows the enhanced length of tomato ripening which increased its shelf life up to 32 days and found best as compared with control and other treatments. Similar findings were reported by Khairi et al. (2018) in tomatoes stored in different conditions.

\section{Conclusion}

The findings of present investigations conclude that when the salicylic acid concentration increased from 50 ppm to $200 \mathrm{ppm}$, the shelf life also increased. It was observed that the shelf life was recorded higher (32 days) in the tomatoes treated with 200 ppm salicylic acid concentration. The effect of storage temperatures of treated fruits on shelf life was also investigated and recorded the highest shelf life (32 days) at $24^{\circ} \mathrm{C}$ storage temperature as compared to the control sample storage (12 days). SA has the potential to maintain the physicochemical properties by delaying the ripening process and retarding the internal gaseous changes which occur during storage. It concluded from the current experiments that salicylic acid is valuable for postharvest treatment for enhancing the shelf life of tomato fruit. Furthermore, it could be suggested for usage in international as well as local markets for extending the shelf life of horticultural produces. SA treatment can be easy and safe used for delaying/shifting ripening processes of tomato with improving fruit quality during shelf-life.

\section{Conflict of Interest}

The authors declare no conflict of interest. 


\section{Acknowledgements}

The authors are thankful to Council of Scientific and Industrial Research (CSIR), Ministry of Human Resource Development Group, Govt. of India, New Delhi for providing individual research fellowship to the Senior Research Fellow (SRF) which helped the research scholar to carry out the research work smoothly.

\section{References}

AOAC. (2016). Official Methods of Analysis of AOAC international, 20th ed. Washington, D.C., USA: Association of Official Analytical Chemists.

Asghari, M. and Aghdam, M.S. (2010). Impact of salicylic acid on post-harvest physiology of horticulture crops. Trends in Food Science and Technology, 21(10), 502-509. https:// doi.org/10.1016/j.tifs.2010.07.009

Bai, J., Baldwin, E.A., SolivaFortuny, R.C., Matthesis, J.P., Stanley, R., Perera, C. and Brecht, J.K. (2004). Effect of pretreatment of intact 'Gala'apple with ethanol vapor, heat, or 1-methylcyclopropene on quality and shelf life of fresh-cut slices. Journal of American Society for Horticulture Science, 129(4), 583-593.

JASHS.129.4.0583

Bhowmik, S.R. and Pan, J.C. (1992). Shelf life of mature green tomatoes stored in controlled atmosphere and high humidity. Journal of Food Science, 57(4), 948953. https://doi.org/10.1111/j.13652621.1992.tb14331.x

Dokhanieh, A.Y., Aghdam, M.S., Fard, J.R. and Hassanpour, H. (2013). Postharvest salicylic acid treatment enhances antioxidant potential of cornelian cherry fruit. Scientia Horticulturae, 154, 31-36. https://doi.org/10.1016/j.scienta.2013.01.025

Fish, W.W., Perkins-Veazie, P. and Collins, J.K. (2002).

A quantitative assay for lycopene that utilizes reduced volumes of organic solvents. Journal of Food Composition Analysis, 15(3), 309-317. https:// doi.org/10.1006/jfca.2002.1069

Fung, R., Wang, C., Smith, D., Gross, K. and Tian, M. (2004). MeSA and MeJA increase steady-state transcript levels of alternative oxidase and resistance against chilling injury in sweet peppers (Capsicum annuum L.). Plant Sciences, 166(3), 711-719. https:// doi.org/10.1016/j.plantsci.2003.11.009

Gharezi, M., Joshi, N. and Sadeghian, E. (2012). Effect of post-harvest treatment on stored cherry tomatoes. Journal of Nutrition and Food Science, 2(8), 1-10. https://doi.org/10.4172/2155-9600.1000157

Khachik, F., Carvalho, L., Bernstein, P.S., Muir, G.J., Zhao, D.Y. and Katz, N.B. (2002). Chemistry, distribution and, metabolism of tomato carotenoids and their impact on human health. Experimental Biology and Medicine, 227(10), 845-851. https:// doi.org/10.1177/153537020222701002

Khairi, A.N., Falah, M.A.F., Pamungkas, A.P. and Takahashi, N. (2018). Optimization of storage temperatures to maintain Lycopene content of tomato from moderate water stress irrigated greenhouse. In IOP Conference Series: Materials Science and Engineering, 403(1), 012051. https:// doi.org/10.1088/1757-899X/403/1/012051

Lelievre, J.M., Latch, A., Jones, B., Bouzayen, M. and Pech, J.C. (1997). Ethylene and fruit ripening. Physiologia Plantarum, 101(4), 727-739. https:// doi.org/10.1111/j.1399-3054.1997.tb01057.x

Mandal, D., Pautu, L., Hazarika, T.K., Nautiyal, B.P. and Shukla, A.C. (2016). Effect of salicylic acid on physico-chemical attributes and shelf life of tomato fruits at refrigerated storage. Internationa Journal of Bio-resourse and Stress Management, 7(6), 12721278.

https://doi.org/10.23910/

IJBSM/2016.7.6.1683b

Nunes, M.C.N. (2008). Colour Atlas of postharvest quality of fruits and vegetables., p. 239-243. USA: John Wiley and Sons, INC. https:// doi.org/10.1002/9780813802947

Park, C.-Y., Kim, Y.-J. and Shin, Y. (2016). Effects of an ethylene absorbent and 1-methylcyclopropene on tomato quality and antioxidant contents during storage. Horticulture and Environment Biotechnology, 57(1), 38-45. https:// doi.org/10.1007/s13580-016-0130-9

Ranveer, R.C., Patil, S.N. and Sahoo, A.K. (2013). Effect of different parameters on enzyme-assisted extraction of lycopene from tomato processing waste. Food and Bioproducts Processing, 91(4), 370 -375. https://doi.org/10.1016/j.fbp.2013.01.006

Rao, A.V. and Agarwall, S. (2000). Role of antioxidant lycopene in cancer and heart disease. Journal of the American College of Nutrition, 19(5), 563-569. https://doi.org/10.1080/07315724.2000.10718953

Sisler, E.C. and Serek, M. (1997). Inhibitors of ethylene responses in plants at the receptors level: recent developments. Physiologia Plantarum, 100(3), 577582. https://doi.org/10.1111/j.13993054.1997.tb03063.x

Srivastava, M.K. and Dwivedi, U.N. (2000). Delayed ripening of banana fruit by salicylic acid. Plant Science, 158(1-2), 87-96. https://doi.org/10.1016/ S0168-9452(00)00304-6

Xie, B.X., Gu, Z.Y., Wang, S., Zhuang, H.W., Zeng, J.X., and Zeng, J.Q. (2009). Effect of 1-MCP on texture properties of fresh fruit in storage shelf period of Zizyphus jujuba 'Zhongqiusucui. ISHS Acta Horticulturae, 840, 499-504. https:// doi.org/10.17660/ActaHortic.2009.840.70 